\author{
Anita Perska \\ Uniwersytet Ekonomiczny w Poznaniu
}

\title{
Wydatki inwestycyjne jednostek samorządu terytorialnego jako instrument wspierania przedsiębiorczości
}

\author{
Investment expenditures of territorial government as an instrument supporting \\ entrepreneurship
}

\begin{abstract}
Streszczenie
Do instrumentów wspierania przedsiębiorczości zalicza się m.in. instrumenty polityki wydatkowej samorządów terytorialnych. Przykładem tego rodzaju instrumentu są wydatki inwestycyjne, które mają charakter powszechny i są związane przede wszystkim z inwestycjami infrastrukturalnymi. Władze samorządowe, decydując o poziomie wydatków inwestycyjnych i kierunkach ich wydatkowania, mogą stwarzać warunki sprzyjające rozwojowi przedsiębiorczości, co w konsekwencji może przyczynić się do rozwoju społeczno-gospodarczego. Celem artykułu jest analiza poziomu i dynamiki sumy wydatków inwestycyjnych na 1 mieszkańca jednostek samorządu terytorialnego w latach 1999-2012. Określa się w nim średnioroczne tempo zmian wydatków inwestycyjnych na 1 mieszkańca poszczególnych szczebli jednostek samorządu terytorialnego. Ponadto wskazuje się tendencję kształtowania udziału wydatków inwestycyjnych na 1 mieszkańca w wydatkach ogółem na 1 mieszkańca poszczególnych szczebli jednostek samorządu terytorialnego. Problem badawczy jest ujęty ilościowo. Przetwarzanie materiałów oparte jest na analizie logicznej, dedukcji oraz analogii.
\end{abstract}

\begin{abstract}
Instruments laid down in the territorial governments spending policies are useful tools to support entrepreneurship. Investment expenditures might serve as an example of such instruments as they are commonly used, and they are primarily related to infrastructural investments. The local and regional government authorities, which decide on the level of investment expenditures and their directions, may create conditions, which favor the development of entrepreneurship. Consequently, it may contribute to a socio-economic development. In the article, the author analyzes the investment expenditures per capita in the years 1999-2012. The aim of this article is to analyze the level and dynamics of amounts spent on investment per capita in the above mentioned period. Further, it presents the analysis of the pace of average annual changes in the investment expenditures per capita on the particular levels of the territorial government units. Finally, it discusses the tendency of the share of investment expenditures per capita in general expenditures per capita. The research problem is approached quantitatively and the materials are processed based on a logical analysis, deduction and analogy.
\end{abstract}

Słowa kluczowe: przedsiębiorczość; rozwój społeczno-gospodarczy; samorząd terytorialny; wydatki inwestycyjne

Key words: entrepreneurship; investment expenditures; socio-economic development; territorial government 


\section{Wprowadzenie}

Rozwój przedsiębiorczości może być wspierany przez różne podmioty. Przykładem podmiotu sektora publicznego, który odgrywa ważną rolę w rozwoju przedsiębiorczości, jest samorząd terytorialny. Jednostki samorządu terytorialnego mogą za pomocą polityki dochodowej i wydatkowej kreować warunki do rozwoju przedsiębiorczości. Istotnym instrumentem wspierania przedsiębiorczości, należącym do polityki wydatkowej samorządów terytorialnych, są wydatki inwestycyjne. Celem artykułu jest analiza poziomu i dynamiki sumy wydatków inwestycyjnych na 1 mieszkańca jednostek samorządu terytorialnego w latach 1999-2012. Określa się w nim średnioroczne tempo zmian wydatków inwestycyjnych na 1 mieszkańca poszczególnych szczebli samorządu terytorialnego. Ponadto wskazuje się tendencję kształtowania się udziału wydatków inwestycyjnych na 1 mieszkańca w wydatkach ogółem na 1 mieszkańca poszczególnych szczebli samorządu terytorialnego. Procedura badawcza składa się z czterech etapów: 1. analizy literatury na temat instrumentów wspierania przedsiębiorczości przez samorządy terytorialne,

2. analizy literatury na temat samorządowych wydatków inwestycyjnych,

3. analizy danych wtórnych,

4. wnioskowania.

Źródłem danych wtórnych jest Bank Danych Lokalnych Głównego Urzędu Statystycznego (BDL GUS). Przetwarzanie materiałów oparte jest na analizie logicznej, dedukcji oraz analogii. Problem badawczy jest ujęty ilościowo.

\section{Instrumenty wspierania przedsiębiorczości}

W literaturze ekonomicznej występuje wiele definicji przedsiębiorczości. W Encyklopedii zarządzania określa się przedsiębiorczość jako rodzaj działalności charakteryzującej się twórczym myśleniem oraz twórczym podejściem do zasobów ludzkich i rzeczowych, którymi rozporządza przedsiębiorstwo, w celu wykorzystania wszelkich szans, jakie przynosi rozwój nauki i techniki (Saar, 2011: 10 za Penc, J. 2008. Encyklopedia zarzadzania, podstawowe kategorie i terminy, Łódź). Pobudzanie rozwoju przedsiębiorczości może odbywać się za pośrednictwem różnych podmiotów i różnych instrumentów. Istotne znaczenie w stymulowaniu przedsiębiorczości mają jednostki samorządu terytorialnego, zwłaszcza na poziomie gminnym.

Stosowane przez gminy formy wsparcia można podzielić na instrumenty organizacyjne i ekonomiczne (ryc. 1). Do instrumentów organizacyjnych zalicza się m.in. działalność informacyjną, działalność doradczo-szkoleniową i tworzenie klimatu inwestycyjnego. Wśród instrumentów ekonomicznych możemy wyróżnić dwie kategorie instrumentów związanych z prowadzoną polityką budżetową: instrumenty polityki dochodowej i wydatkowej (Szewczuk, Kogut-Jaworska, Zioło, 2011: 196). Instrumenty polityki dochodowej związane są z instrumentami polityki fiskalnej (m.in. podatek od nieruchomości, opłata targowa, opłata administracyjna), instrumenty związane z gospodarowaniem mieniem, np. wpływy ze sprzedaży gruntów, wpływy z najmu lub dzierżawy) oraz instrumenty polityki cenowej (np. wysokość ceny za wodę i ścieki, ceny za bilety komunikacji zbiorowej). Instrumenty wspierania przedsiębiorczości w zakresie polityki wydatkowej dotyczą przede wszystkim działań polegających na tworzeniu infrastruktury technicznej, takich jak budowa sieci wodociągowej i kanalizacyjnej, budowa i remonty dróg, zapewnienie sieci łączności oraz infrastruktury społecznej, m.in. budowa szkół, przychodni, budowa i remonty mieszkań (Szewczuk, Kogut-Jaworska, Zioło, 2011: 199).

Dobre wyposażenie jednostki terytorialnej w infrastrukturę techniczną i społeczną tworzy stan dogodności lokalizacyjnej dla inwestorów i mieszkańców, czyniąc ją bardziej atrakcyjną 
Ryc. 1. Instrumenty wspierania przedsiębiorczości przez jednostki samorządu terytorialnego w Polsce

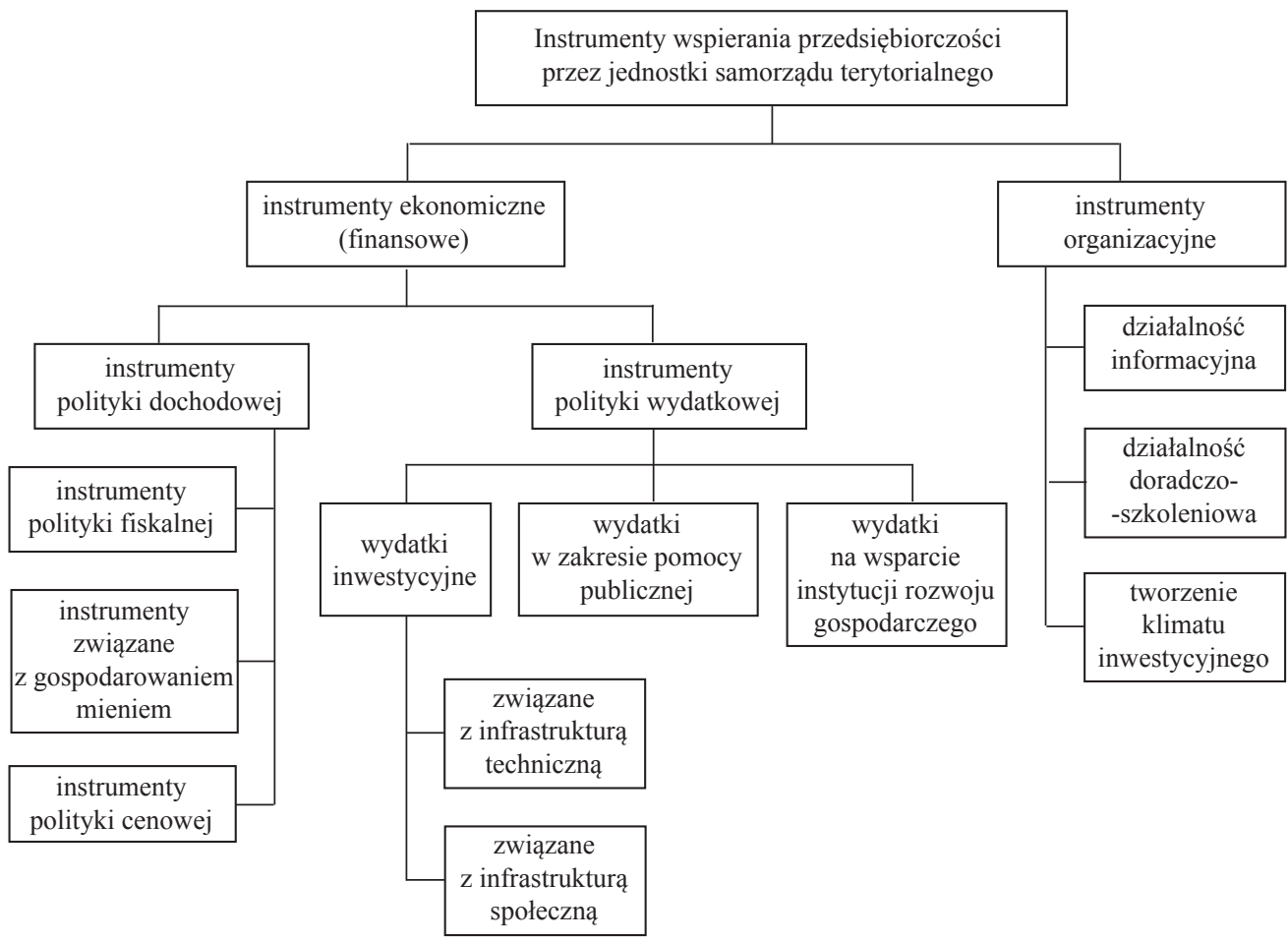

Źródło: opracowanie własne na podstawie Szewczuk, Kogut-Jaworska, Zioło (2011: 200-201).

pod różnymi względami. Infrastruktura stanowi kluczowy element struktury funkcjonalno-przestrzennej, odgrywając różną rolę w życiu społeczno-gospodarczym, w tym sprzyjając (lub nie) podejmowaniu działalności gospodarczej. Z punktu widzenia ekonomicznego istotne znaczenie ma dostępność infrastruktury zarówno pod względem przestrzennym, jak i finansowym (Wojciechowski, 2012: 223-224).

Samodzielność w zakresie kreowania wydatków gmin jest większa aniżeli samodzielność w kształtowaniu dochodów, gdzie występują sztywniejsze ograniczenia ustawowe. Tym samym gminy mają o wiele większe możliwości w stosowaniu instrumentów o charakterze wydatkowym niż dochodowym. W odróżnieniu od instrumentów dochodowych, które określane są jako bierne, instrumenty wydatkowe cechuje charakter czynny. Ponadto, o ile instrumenty dochodowe są wykorzystywane wyłącznie przez gminy, o tyle instrumenty wydatkowe mogą być stosowane przez wszystkie jednostki samorządu terytorialnego (Kogut-Jaworska, 2008: 104), stąd w niniejszym artykule analizie poddana zostanie polityka wydatkowa ze szczególnym uwzględnieniem wydatków inwestycyjnych gmin, powiatów i województw.

\section{Wydatki jednostek samorządu terytorialnego}

Wydatki jednostek samorządu terytorialnego stanowią część wydatków publicznych. Już w 1892 r. A. Wagner wyciągnął wniosek, że z rozwojem społecznym rosną wydatki, a wręcz, że rozwój nowoczesnego państwa wymaga stale rosnących wydatków. Jest to tzw. prawo stałego wzrostu 
wydatków publicznych, zwane także prawem stale rosnących potrzeb finansowych (Juja, 2011: 261). Zgodnie z prawem Wagnera występuje stały wzrost wydatków publicznych (względnych w odniesieniu do PKB i bezwzględnych), czyli środków pieniężnych przeznaczonych na realizację przedsięwzięć państwowych i samorządowych. W 2009 r. udział wydatków jednostek samorządu terytorialnego ogółem w wydatkach sektora finansów publicznych ogółem wynosił 28,4\% (Filipiak, 2011: 24).

Zgodnie z art. 163 Konstytucji Rzeczypospolitej Polskiej samorząd terytorialny wykonuje zadania publiczne niezastrzeżone przez Konstytucję lub ustawy dla innych organów władz publicznych (tzw. klauzula generalna). Finanse samorządowe odnoszą się do realizacji zadań o zasięgu lokalnym, które zmierzają do zaspokojenia potrzeb zbiorowości samorządowych. Wpływ na zakres i strukturę samorządowych wydatków budżetowych wywiera społeczno-polityczny ustrój kraju oraz stopień decentralizacji i podział zadań między władze centralne i samorządowe (Jastrzębska, 2012: 131). Decentralizacja finansowa rozumiana jako przekazanie na rzecz jednostek samorządu terytorialnego odpowiednich publicznych zasobów finansowych i władztwa do dysponowania nimi (Kasperowicz-Stępień, 2010: 74) zapewniła samorządom możliwość decydowania o dokonywaniu wydatków na zaspokajanie potrzeb społeczności lokalnych i kształtowanie priorytetów rozwojowych. Podstawową jednostką terytorialną jest gmina i to właśnie na nią ustawodawca nałożył szereg zadań, które są najbliższe wspólnotom lokalnym. Reformy decentralizacyjne lat 90 . XX w. polegały na przekazaniu szerokiego zakresu zadań samorządom gminnym i znacznie węższego powiatom i samorządom województw. Zagregowane budżety gmin są większe aniżeli zagregowane budżety powiatów i województw, a prawidłowości tej nie zmienił rosnący w ostatnich latach zakres kompetencji samorządów wojewódzkich (Swianiewicz, 2011: 216).

Finanse jednostek samorządu terytorialnego jako finanse jednostek sektora publicznego, zostały uwzględnione w Ustawie z dnia 27 sierpnia 2009 r. o finansach publicznych (z późn. zmianami; dalej: u.f.p.). Zgodnie z art. 44 tej ustawy wydatki publiczne mogą być ponoszone wyłącznie na cele i w wysokości ustalonych w ustawie budżetowej, uchwale budżetowej jednostki samorządu terytorialnego lub w planie finansowym jednostki sektora finansów publicznych, zgodnie z przepisami dotyczącymi poszczególnych rodzajów wydatków (co przesądza o ich szczególnym statusie). Zgodnie z art. 52 powyższej ustawy wydatki publiczne ujęte w budżetach jednostek sektora finansów publicznych stanowią nieprzekraczalny limit. W planie wydatków budżetu jednostki samorządu terytorialnego wyszczególnia się, w układzie działów i rozdziałów klasyfikacji budżetowej, planowane kwoty wydatków bieżących i wydatków majątkowych (tab. 1), a wśród wydatków majątkowych wyróżnić można majątkowe wydatki inwestycyjne ${ }^{1}$, które w niniejszym artykule zwane są wydatkami inwestycyjnymi.

Analiza struktury wydatków pozwala na dokonanie oceny stopnia zaangażowania środków samorządowych na cele inwestycyjne. Należy zaznaczyć, że wielkość wydatków majątkowych zależy przede wszystkim od poziomu dochodów własnych i możliwości pokrycia tymi dochodami zaciągniętych zobowiązań inwestycyjnych (Ruśkowski, 2007: 162). Kwoty wydatków bieżących i wydatków majątkowych zapisywane są zgodnie z Rozporządzeniem Ministra Finansów z 2 marca 2010 r. w sprawie szczegółowej klasyfikacji dochodów, wydatków, przychodów i rozchodów oraz środków pochodzących ze źródeł zagranicznych (np. dział 010

\footnotetext{
${ }^{1}$ Przykładowo, dla gmin w 2012 r. majątkowe wydatki inwestycyjne na 1 mieszkańca stanowiły 96,64\% wydatków majątkowych na 1 mieszkańca i 18,25\% całkowitych wydatków budżetowych na 1 mieszkańca.
} 
Tab. 1. Wydatki bieżące i wydatki majątkowe jednostek samorządu terytorialnego

\begin{tabular}{|c|c|}
\hline Wydatki bieżące (pkt. 3 art. 236 u.f.p.) & Wydatki majątkowe (pkt. 4 art. 236 u.f.p.) \\
\hline $\begin{array}{l}\text { - wydatki jednostek budżetowych, w tym na wy- } \\
\text { nagrodzenia i składki od nich naliczane oraz } \\
\text { wydatki związane z realizacją ich statutowych } \\
\text { zadań } \\
\text { - dotacje na zadania bieżące } \\
\text { - świadczenia na rzecz osób fizycznych } \\
\text { - wydatki na programy finansowane z udziałem } \\
\text { środków, o których mowa w art. } 5 \text { ust. } 1 \text { pkt. } 2 \\
\text { i } 3 \text {, w części związanej z realizacją zadań jed- } \\
\text { nostki samorządu terytorialnego } \\
\text { - wypłaty z tytułu poręczeń i gwarancji udzielo- } \\
\text { nych przez jednostkę samorządu terytorialnego } \\
\text { przypadające do spłaty w danym roku budże- } \\
\text { towym } \\
\text { - obsługa długu jednostki samorządu terytorial- } \\
\text { nego }\end{array}$ & $\begin{array}{l}\text { - inwestycje i zakupy inwestycyjne, w tym na } \\
\text { programy finansowane z udziałem środków, } \\
\text { o których mowa w art. } 5 \text { ust. } 1 \text { pkt. } 2 \text { i } 3 \text {, } \\
\text { w części związanej z realizacją zadań jednost- } \\
\text { ki samorządu terytorialnego } \\
\text { - zakup i objęcie akcji oraz udziałów } \\
\text { - wniesienie wkładów do spółek prawa handlo- } \\
\text { wego }\end{array}$ \\
\hline
\end{tabular}

Źródło: opracowanie własne na podstawie art. 236 Ustawy z dnia 27 sierpnia 2009 r. o finansach publicznych (z późn. zm.)

rolnictwo i łowiectwo, dział 700 gospodarka mieszkaniowa). Ponadto, zgodnie z art. 44 u.f.p. wydatki jednostek samorządu terytorialnego, należące do kategorii wydatków publicznych, mogą być ponoszone na cele i w wysokości ustalonych w uchwale budżetowej i powinny być dokonywane:

- w sposób celowy i oszczędny z zachowaniem zasad: uzyskiwania najlepszych efektów z danych nakładów oraz optymalnego doboru metod i środków służących osiągnięciu założonych celów,

- w sposób umożliwiający terminową realizację zadań,

- w wysokości i terminach wynikających z wcześniej zaciągniętych zobowiązań.

W zakresie kształtowania wydatków obowiązuje zasada samodzielności finansowej. Zasada ta przejawia się w uprawnieniu organów do ustalania hierarchii potrzeb i wyboru form finansowania, przy uwzględnieniu konieczności realizacji zadań i wydatków obligatoryjnych. Jednostki samorządu terytorialnego mają prawo decydowania o podziale środków finansowych na zadania bieżące i inwestycyjne. Występuje samodzielność decydowania o przyznaniu dotacji z budżetu oraz o wyborze podmiotu dotowanego. Ponadto jednostki samorządu terytorialnego mają prawo wyboru formy i sposobu wydatkowania środków, np. jednostka samorządu terytorialnego finansuje zadanie bezpośrednio z budżetu, przez własną jednostkę organizacyjną, lub zleca zadanie do wykonania podmiotowi z lub spoza sektora finansów publicznych. Wydatkowanie środków odbywa się w trybach przewidzianych w ustawie o zamówieniach publicznych, jednakże o wyborze trybu decydują samodzielnie organy jednostek samorządu terytorialnego (Glumińska-Pawlic, 2008: 278-279).

Samodzielności finansowa jednostek samorządu terytorialnego w pewnym zakresie kształtowania wydatków jest ograniczona. Następuje ustawowa hierarchizacja zadań własnych samorządów terytorialnych: wydatki budżetowe muszą w pierwszym rzędzie zapewnić stałe i nieprzerwane wykonywanie obligatoryjnych zadań własnych, a następnie zapewnić funkcjonowanie wszystkich organów. Dotacje przyznane na realizację zadań zleconych z zakresu 
administracji rządowej należy wykorzystać zgodnie z przeznaczeniem. Samodzielność finansowa jednostek samorządu terytorialnego jest tym większa, im większy jest udział wydatków przeznaczonych na zadania własne, a mniejszy - na zadania zlecone (Glumińska-Pawlic, 2008: 278-279).

Wyróżnia się różne źródła pochodzenia środków, z których finansowane są wydatki inwestycyjne samorządów w Polsce. Do końca lat 90. XX w. główne źródło finansowania inwestycji stanowiły środki własne pochodzące z dochodów bieżących samorządów i z majątku. Sytuacja zaczęła zmieniać się wraz z upowszechnieniem instrumentów dłużnych i funduszy unijnych. Kolejnym źródłem są dotacje ze środków publicznych: dotacje z budżetu państwa i dotacje z funduszy celowych (największe znaczenie odgrywa Narodowy Fundusz i Wojewódzkie Fundusze Ochrony Środowiska i Gospodarki Wodnej oraz Krajowy Fundusz Mieszkaniowy). Polityka funduszy ochrony środowiska prowadziła do ograniczania udzielanych dotacji i zastępowania ich pożyczkami preferencyjnymi. Kolejnym źródłem finansowania inwestycji są środki zwrotne: pożyczki i kredyty o charakterze preferencyjnym, kredyty komercyjne zaciągane w bankach i obligacje komunalne. Ponadto polskie samorządy terytorialne, realizując inwestycje, mogły skorzystać ze środków pomocowych, pochodzących przede wszystkim z Unii Europejskiej (fundusze przedakcesyjne, np. PHARE2, ISPA, SAPARD i środki z funduszy dostępnych po akcesji w perspektywie finansowej 2007-2013). Powyższe źródła finansowania inwestycji należy uzupełnić o środki pozyskane w ramach partnerstwa publiczno-prywatnego, które cechuje tendencja rosnąca, ale nadal jest ono rzadko wykorzystywane (Swianiewicz, 2011: 228-234).

\section{Samorządowe wydatki inwestycyjne}

Suma wydatków inwestycyjnych na 1 mieszkańca jednostek samorządu terytorialnego w latach 1999-2012 charakteryzowała się niestałą tendencją (ryc. 2). W 1999 r. wydatki te wynosiły 321,64 zł, natomiast w 2012 r. - 892,76 zł, co oznacza, że omawiane wydatki w 2012 r. stanowiły ok. 277,6\% wydatków z 1999 r. (tj. były ok. 2,8 razy większe). W latach 1999-2001 omawiane wydatki rosły, po czym w 2002 r. i 2003 r. nastąpił spadek. Od 2004 r. następował wzrost do 2010 r., natomiast w 2011 r. i 2012 r. wartość wydatków uległa obniżeniu. Średnioroczne tempo zmian ${ }^{2}$ wynosiło ok. $8,17 \%$.

Ryc. 2. Suma wydatków inwestycyjnych na 1 mieszkańca jednostek samorządu terytorialnego w latach 1999-2012 w Polsce

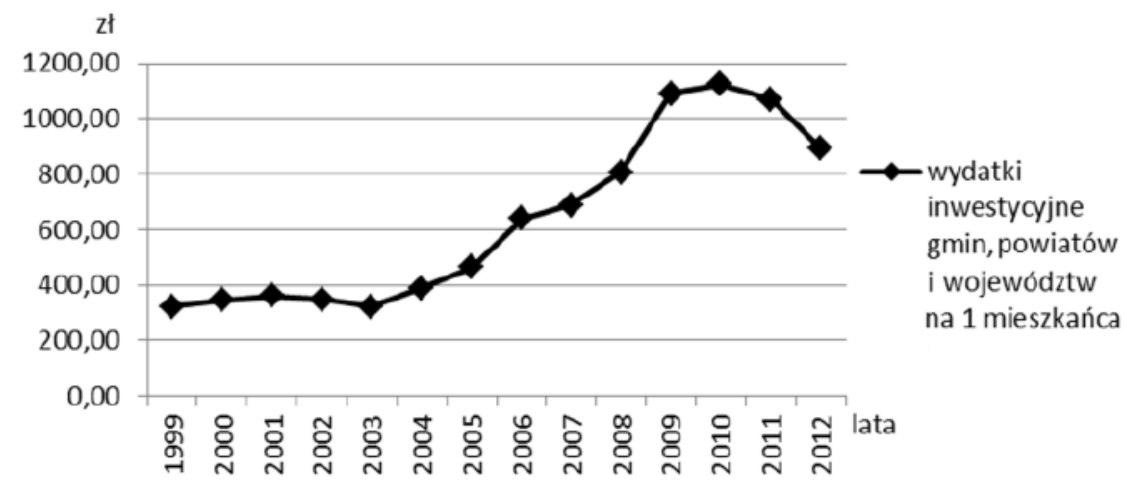

Źródło: opracowanie własne na podstawie danych BDL GUS (2013).

2 Średnie tempo zmian cechy zostało określone zgodnie ze wzorem $\left(\bar{y}_{g}, 1\right) \rtimes 00$, gdzie $\overline{y_{g}}=\sqrt[n n d]{\frac{y_{n}}{y_{1}}}$ (http://www.stat.gov.pl/gus/definicje_PLK_HTML.htm?id=POJ-7531.htm, pobrano: 27.03.2014). 
Spadek wydatków inwestycyjnych na 1 mieszkańca jednostek samorządu terytorialnego w latach 2002 i 2003 oraz 2011 i 2012 mógł wynikać ze spowolnienia gospodarczego przypadającego na te okresy. Aby móc szczegółowo wnioskować o przyczynach wahań wartości tych wydatków, należy dokonać dokładnej analizy z podziałem na wydatki gmin, powiatów i województw, co następuje poniżej.

Tendencje kształtowania się wydatków inwestycyjnych na 1 mieszkańca poszczególnych szczebli jednostek samorządu terytorialnego w latach 1999-2012 są podobne (ryc. 3). W 2012 r. omawiane wydatki gmin stanowiły 242,3\% wydatków z 1999 r., a pozostałych jednostek samorządu terytorialnego odpowiednio: wydatki powiatów - 435,1\% i wydatki województw 543,0\%. Największe średnioroczne tempo zmian charakteryzowało województwa - ok. 14\%, następnie powiaty - ok. 12\% i gminy - ok. 7\%. Podczas gdy tendencje kształtowania się wydatków inwestycyjnych na 1 mieszkańca gmin i powiatów są podobne, w przypadku województw w 2009 r. nastąpił znaczny wzrost, po czym w 2010 r. zaobserwowano spadek, w 2011 r. nieznaczny wzrost i w 2012 r. ponownie spadek.

Ryc. 3. Wydatki inwestycyjne na 1 mieszkańca poszczególnych szczebli jednostek samorządu terytorialnego w latach 1999-2012 w Polsce

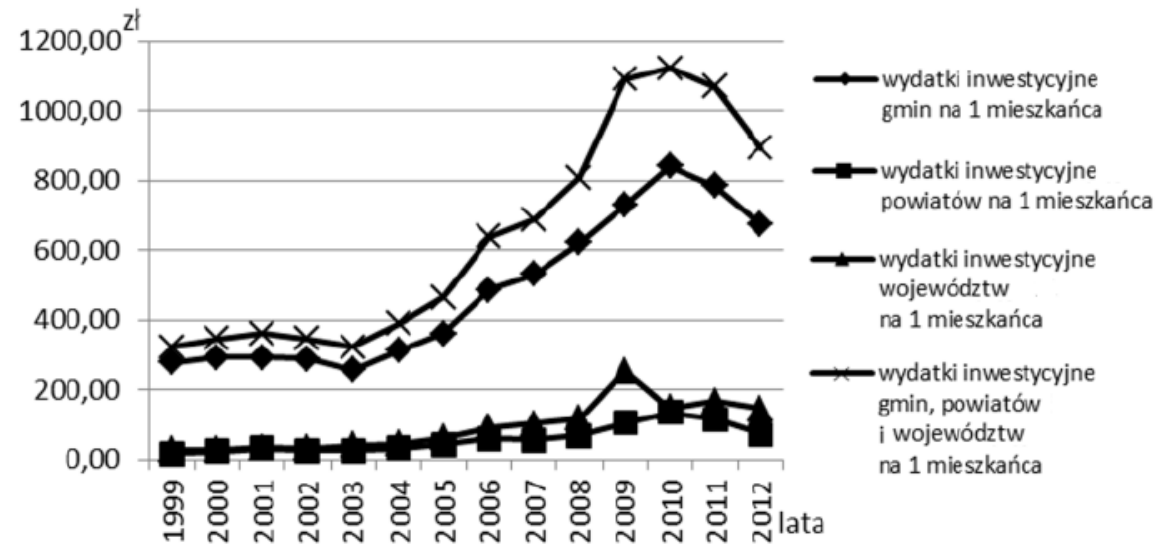

Źródło: Opracowanie własne na podstawie danych BDL GUS (2013).

W ostatnich latach obserwuje się spadek wydatków inwestycyjnych na 1 mieszkańca poszczególnych szczebli jednostek samorządu terytorialnego. Można uznać, że województwa jako pierwsze już w 2010 r. obniżyły wydatki inwestycyjne na mieszkańca. Spadek ten mógł być związany z postępującym spowolnieniem gospodarczym w kraju. Ponadto współwystępowało to $\mathrm{z}$ ostatnimi latami realizowania projektów rozwojowych $\mathrm{z}$ funduszy unijnych $\mathrm{w}$ perspektywie finansowej 2007-2013. Możliwe jest również zakończenie priorytetowych inwestycji w latach poprzednich, zwłaszcza inwestycji kapitałochłonnych. Realizacja takich inwestycji wymagała wkładów własnych samorządów terytorialnych, co w konsekwencji mogło doprowadzić do osiągnięcia znacznego zadłużenia jednostki terytorialnej, spowolnienia dotychczasowych działań inwestycyjnych i odłożenia w czasie rozpoczęcia realizacji nowych inwestycji. Powyższe przyczyny spadku wydatków inwestycyjnych na mieszkańca dotyczą również gmin i powiatów.

Szczególnie istotną rolę w przypadku gmin odgrywają dochody własne. Chodzi tu o wpływy z podatku od osób fizycznych i prawnych oraz jednostek organizacyjnych niemających osobowości prawnej, mających siedzibę na terenie gminy. W ostatnich latach następuje spadek wpływów 
z podatków. Na łamach „Wspólnoty” Zdzisława Wasążnik, dyrektor Departamentu Finansów Samorządu Terytorialnego w Ministerstwie Finansów, wskazywała, że skutki kryzysu ekonomicznego w postaci niższych dochodów odczują przede wszystkim te jednostki, których dochody w budżecie w większym stopniu oparte są na dochodach podatkowych. W mniejszym stopniu spadek dochodów wpłynie na samorządy terytorialne, w których w strukturze dochodów ogółem dochody z tytułu subwencji ogólnej stanowią podstawowe źródło. Ponadto w badanym okresie jednostki samorządu terytorialnego nie otrzymały rekompensaty za obniżenie stawek podatku PIT czy też za wprowadzenie ulg rodzinnych (Osiecki, 2012).

Udział wydatków inwestycyjnych na 1 mieszkańca w wydatkach ogółem na 1 mieszkańca jednostek samorządu terytorialnego w latach 1999-2012 charakteryzował się niestałą tendencją (ryc. 4). W 2012 r. największy udział cechował województwa - 35,94\%, następnie gminy $18,25 \%$, natomiast najmniejszy powiaty - 12,35\%. Wydatki majątkowe służą powiększaniu majątku jednostek samorządu terytorialnego (np. budowa i rozbudowa obiektów komunalnych). Chociaż realizacja tych zadań wynika z przepisów ustawowych, w przeciwieństwie do zadań bieżących, w trudnej sytuacji finansowej można odsunąć ich realizację w czasie (Harańczyk, 2010: 141).

Ryc. 4. Udział wydatków inwestycyjnych na 1 mieszkańca w wydatkach ogółem na 1 mieszkańca jednostek samorządu terytorialnego w latach 1999-2012 w Polsce

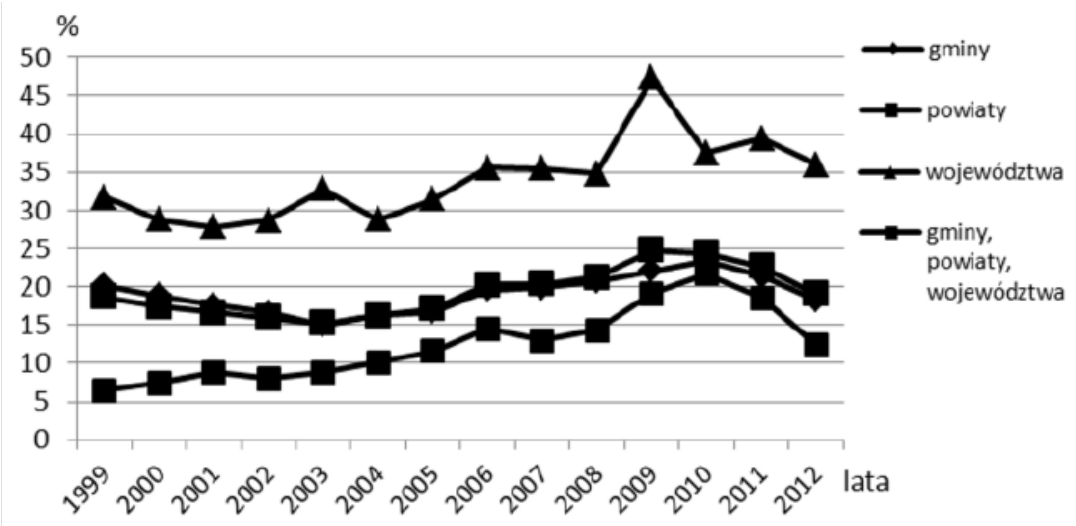

Źródło: opracowanie własne na podstawie danych BDL GUS (2013).

Udział wydatków inwestycyjnych na 1 mieszkańca w wydatkach ogółem na 1 mieszkańca jednostek samorządu terytorialnego wynika ze struktury budżetowej szczególnych szczebli jednostek samorządu terytorialnego. Duży udział badanych wydatków w przypadku województw może być związany z realizacją kapitałochłonnych inwestycji. Z kolei mniejszy udział wydatków inwestycyjnych 1 mieszkańca w wydatkach ogółem na 1 mieszkańca oznacza, że jednostka terytorialna dysponuje niewielkimi dochodami własnymi, a zadania, które realizuje, wymagają ponoszenia wydatków o charakterze bieżącym. Taka sytuacja występuje w powiatach, w których poziom wydatków na działalność inwestycyjną jest najniższy (Harańczyk, 2010: 145-146).

\section{Zakończenie}

Poziom wydatków zdeterminowany jest podziałem zadań pomiędzy państwo a samorząd oraz w ramach samorządu terytorialnego - pomiędzy gminy, powiaty i województwa. Wykonywanie 
zadań związane jest z obowiązkiem ich finansowania, a możliwość dokonywania wydatków uwarunkowana jest uzyskiwaniem dochodów. W latach 2003-2010 następował wzrost sumy wydatków inwestycyjnych na 1 mieszkańca jednostek samorządu terytorialnego (gmin, powiatów, województw), natomiast w 2011 r. i 2012 r. nastąpił spadek tych wydatków (od 2011 r. spadek wydatków inwestycyjnych na 1 mieszkańca gmin i powiatów, a w 2010 r. i 2012 r. województw). W latach 1999-2012 największa wartość wydatków inwestycyjnych na 1 mieszkańca występowała na szczeblu gmin, co jest związane z realizacją największej liczby zadań publicznych. W ostatnim analizowanym roku największa wartość wydatków inwestycyjnych na 1 mieszkańca cechowała gminy, następnie województwa i powiaty. W 2011 r. i 2012 r. nastąpił spadek udziału wydatków inwestycyjnych na 1 mieszkańca w wydatkach ogółem gmin i powiatów, a w 2010 r. i 2012 r. województw. Dalsze badania powinny zostać skoncentrowane na analizie zróżnicowania przestrzennego wydatków inwestycyjnych na 1 mieszkańca. Samorządy terytorialne, wykonując szereg zadań publicznych i będąc odpowiedzialnymi za organizację życia społeczno-gospodarczego, powinny wspierać lokalną przedsiębiorczość przez zastosowanie odpowiednich instrumentów, w tym wydatków inwestycyjnych, co w konsekwencji może przyczynić się do rozwoju społeczno-gospodarczego jednostki terytorialnej.

\section{Literatura References}

Filipiak, B. (2011). Finanse samorządowe, nowe wyzwania bieżące i perspektywiczne, Warszawa: Diffin. Glumińska-Pawlic, J. (2008). Jakie są faktyczne ograniczenia samodzielności finansowej j.s.t. w zakresie kształtowania wydatków? W: C. Kosikowski, (red.), Finanse samorządowe 2008, Warszawa: Wolters Kluwer Polska, 278-279.

Harańczyk, A. (2010). Samorząd terytorialny, organizacja i gospodarka, Kraków: Wydawnictwo Uniwersytetu Ekonomicznego w Krakowie.

Jastrzębska, M. (2012). Finanse jednostek samorzadu terytorialnego, Warszawa: Wolters Kluwer Polska. Juja T. (2011). Finanse publiczne, Poznań: Wydawnictwo Uniwersytetu Ekonomicznego w Poznaniu.

Kasperowicz-Stępień, A. (2010). Decentralizacja wydatków publicznych w krajach Unii Europejskiej. W: T. Juja (red.), Dylematy $i$ wyzwania finansów publicznych, Poznań: Wydawnictwo Uniwersytetu Ekonomicznego w Poznaniu, 74.

Kogut-Jaworska, M. (2008). Instrumenty interwencjonizmu lokalnego w stymulowaniu rozwoju gospodarczego, Warszawa: CeDeWu Sp. z o.o.

Konstytucja Rzeczypospolitej Polskiej z dnia 2 kwietnia 1997 r. z późn. zmianami.

Maśloch, G., Sierak, J. (red.) (2013). Gospodarka i finanse samorządu terytorialnego, Warszawa: Oficyna Wydawnicza SGH w Warszawie.

Ruśkowski, E. (2007). Ogólne zasady wydatków j.s.t. W: E. Ruśkowski, J. Salachna (red.), Finanse lokalne po akcesji, Warszawa: Wolters Kluwer Polska, 162.

Saar, M. (2011). Jak samorząy lokalne moga wspierać rozwój przedsiębiorczości? Warszawa: CeDeWu Sp. z o.o.

Szewczuk, A., Kogut-Jaworska, M., Zioło, M. (2011). Rozwój lokalny i regionalny, teoria i praktyka, Warszawa: Wydawnictwo C.H. Beck.

Swianiewicz P. (2011). Finanse samorzadowe koncepcje, realizacja, polityki lokalne, Warszawa: Międzykomunalna Spółka Akcyjna MUNICIPIUM.

Ustawa z dnia 27 sierpnia 2009 r. o finansach publicznych (z późn. zmianami).

Wojciechowski, E. (2012). Zarządzanie w samorządzie terytorialnym, wyd. II poprawione i poszerzone, Warszawa: Difin. 


\section{Źródla internetowe}

BDL GUS, http://www.stat.gov.pl/bdl/app/strona.html?p_name=indeks (2013, 10 września). http://www.stat.gov.pl/gus/definicje_PLK_HTML.htm?id=POJ-7531.htm

Osiecki, A. (2012, 20 grudnia). Dochody z podatków maleją. Wspólnota. Pozyskano z http://www.wspolnota.org.pl/aktualnosci/aktualnosc/dochody-z-podatkow-maleja/

Anita Perska, mgr, Uniwersytet Ekonomiczny w Poznaniu, Katedra Ekonomiki Przestrzennej i Środowiskowej.

Doktorantka na Uniwersytecie Ekonomicznym w Poznaniu (Katedra Ekonomiki Przestrzennej i Środowiskowej). Zainteresowania: rozwój lokalny i regionalny, współpraca samorządów terytorialnych, gospodarka sieciowa, przedsiębiorczość.

Anita Perska, MSc - a doctoral student at Poznań University of Economics, Department of Spatial and Environmental Economics.

The author's interests relate to the local and regional development, cooperation of territorial government units, network economy, entrepreneurship

Adres/Address: Uniwersytet Ekonomiczny w Poznaniu

Katedra Ekonomiki Przestrzennej i Środowiskowej

al. Niepodległości 10

61-875 Poznań, Polska

e-mail: anita.perska@ue.poznan.pl 